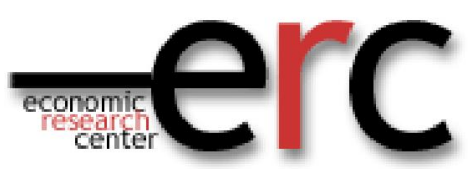

ERC Working Papers in Economics 12/02

Jan 2012

\title{
Turkish Voter Response To Government Incompetence And Corruption Related To The 1999 Earthquakes
}

\author{
Ali T. Akarca \\ Department of Economics (mc 144) \\ University of Illino is at Chicago \\ 601 S. Morgan Street \\ Chicago Illinois 60607, USA \\ Email: akarca@uic.edu \\ and \\ Aysit Tansel \\ Department of Economics \\ Middle East Technical University \\ Ankara 06531 Turkey \\ Email: atansel@metu.edu.tr \\ Tel: 0090(312)2102057 \\ Institute for the Study of Labor (IZA) P. O. Box 7240, \\ D-53072 Bonn, Germany \\ and \\ Economic Research Forum (ERF) Cairo, Egypt
}




\title{
TURKISH VOTER RESPONSE TO GOVERNMENT INCOMPETENCE AND CORRUPTION RELATED TO THE 1999 EARTHQUAKES*
}

\author{
Ali T. Akarca \\ Department of Economics (mc 144) \\ University of Illinois at Chicago \\ 601 S. Morgan Street \\ Chicago Illinois 60607, USA \\ Email: akarca@uic.edu \\ and \\ Aysit Tansel \\ Department of Economics \\ Middle East Technical University \\ Ankara 06531 Turkey \\ Email: atansel@metu.edu.tr \\ Tel: 0090(312)2102057 \\ Institute for the Study of Labor (IZA) P. O. Box 7240, \\ D-53072 Bonn, Germany \\ and \\ Economic Research Forum (ERF) Cairo, Egypt
}

January, 2012

\begin{abstract}
Keywords: Turkey, Natural disaster, Earthquake, Corruption, Government performance, Elections, Voter Behavior, Party preference
\end{abstract}

JEL Classification: D72, D73, $\mathrm{H84}$

\footnotetext{
${ }^{*}$ This work has benefited from a financial grant from the Economic Research Forum within the framework of the Regional Research Competition funded by the Global Development Network. The contents and recommendations do not necessarily reflect the views of the Economic Research Forum. We would like to thank Cengizhan Güder, Mehmet Dikmen and Bülent Özmen for guiding us to the data sources, and to Aydın Bozdemir, Ulvi Askerov, Yasemin Aslan and for assisting us in gathering and organizing the data. Earlier versions of this paper were presented at the $14^{\text {th }}$ Annual Conference of the Economic Research Forum held in Cairo, Egypt, 28-30 December 2007, at the $7^{\text {th }}$ International Conference of the Middle East Economic Association, held in Famagusta, North Cyprus, 29-31 May, 2008, at the 15 $5^{\text {th }}$ World Congress of the International Economic Association, Istanbul, Turkey, June 25-29 2008, an at the $32^{\text {nd }}$ Annual Meeting of the Middle East Economic Association, Chicago, Illinois, USA, 5-8 January 2012. We have benefited greatly from the comments we have received from our audiences at these meetings.
} 


\begin{abstract}
The two major earthquakes which struck northwestern Turkey in 1999, caused enormous amounts of death and destruction, and exposed rampant government corruption involving construction and zoning code violations, as a factor magnifying the disaster. The opposition parties and one of the incumbent parties which participated in previous national governments and held power in current and past municipal administrations were responsible for that. The other two incumbent parties came to power only a short time before the earthquakes and controlled almost none of the local administrations in the disaster zone. They on the other hand, were responsible for the incompetence shown in providing relief, for involvement in corruption related to those efforts, and for failing to prosecute the businessmen who constructed the shoddy buildings and the corrupt officials who permitted them. How voters responded to these in the 2002 parliamentary elections is investigated, using crossprovincial data, controlling for other social, political and economic factors. The fact that different groups of parties were responsible for different types of corruption and mismanagement provided us with a unique data to differentiate between voter responses to corruption and incompetence, and to corruption which has occurred before and after the earthquakes. Our results show that voters punished all of the political parties which participated in governments during the previous decade. The party in charge of the ministry responsible for disaster relief, and parties that controlled more of the city administrations in the quake zone were blamed more. The newly formed Justice and Development Party (AKP) was the main beneficiary of the votes lost by these parties. Our results corroborate the view in the corruption literature that voters react drastically only when the corruption is massive, the information on it highly-credible and well-publicized, involves large number of political parties, not accompanied by competent governance, and a non-corrupt alternative is available.
\end{abstract}




\section{Introduction}

There is a wide body of inter-disciplinary literature which links corruption to various social and economic ills. For example, Escaleras et al. (2007) show that it raises fatalities from earthquakes, and Anbarci et al. (2006) from traffic accidents. Méon and Sekkat (2005), Pellegrini and Gerlagh (2004), Mo (2001), and Mauro (1995) find that it leads to lower investment. Countries with high levels of public sector corruption are found to receive less foreign aid, by Alesina and Weder (2002), and less foreign direct investment, by Habib and Zurawicki (2002). Tanzi and Davoodi (1997), and Mauro (1997) argue that corruption shifts public expenditures from growth-promoting to lowproductivity projects. Murphy et al. (1991, 1993) argue that it drives potential entrepreneurs to rent-seeking activities, or even to becoming corrupt officials themselves. In short, it can be said that corruption leads to lower economic growth through diminished and misallocated resources. ${ }^{1}$ Thus it is undesirable not only on ethical grounds.

To fight corruption, it is necessary to have institutions in place that disseminate relevant information, and voters who act on that information to hold politicians accountable. Costas et al. (2011), Freille et al. (2007), Lederman et al. (2005), Adsera et al. (2003), Brunetti and Weder (2003), and Besley and Burgess (2002) provide evidence on the importance of a free press in reducing corruption. However, as Johnson et al. (2011), Chang et al. (2010), and Golden (2006) point out, corruption exists even in advanced democracies. Worse yet, Costas et al. (2011), Fernández-Vázquez and Rivero (2010), Chang et al. (2010), and Reed (2005) show, through Spanish, Italian, and Japanese examples, that such corruption usually makes very little difference in the reelection fortunes of politicians even when it is public knowledge. Welch and Hibbing (1997), Dimock and Jacobson (1995), and Peters and Welch (1980) provide similar evidence in the case of U.S. Chang et al. (2010), Fernández-Vázquez and Rivero (2010), Manzetti and Wilson (2007) and Golden (2006) offer some explanations as to why this is so. They argue that voters may doubt the information or dismiss it as partisan, especially if the accusations are leveled predominantly against the members of one party. The pool of candidates from which citizens can choose may be seriously restricted in terms of their quality. Also, the voters may take corruptness of an incumbent into account in casting their ballots, but only as one of his/her many attributes. Especially if they believe that the honest challengers will not be able to deliver the same results in terms of economic development and increases in their well-being, many of them may still vote for the

\footnotetext{
${ }^{1}$ It should be noted that some researchers, such as Nye (1989) and Leff (1964) argue that optimal level of corruption may be non-zero. They assert that bribing can be viewed as greasing the wheels of the government, enabling firms to sidestep burdensome government controls. However others dispute the existence of a stable growth-enhancing equilibrium level of corruption. Rose-Ackerman (1997) for example argues that corruption will always escalate to ever higher levels, and Kaufman and Wei (2000) find that in economies where corruption is high and more bribes have to be paid, managers end up allocating more time to public officials and less time to productive work. A more recent and more rigorous study by Swaleheen (2011) shows that the 'grease-in-the-wheel' argument applies only in the cases of very high-corruption countries, and by Carden and Verdon (2010) only in the cases of low-freedom countries . Since such countries do not have fair elections and voter response to speak of, they do not fall under the subject matter of our paper.
} 
corrupt incumbent. Consequently, a politician can offset, at least partially, the negative impact of his/her corrupt behavior by transferring government benefits to his/her constituents, supporting economic policies with which they agree and/or governing competently otherwise. Corrupt incumbents may lose votes but not enough to deny them re-election, as long as they keep the level of corruption in check and do not allow it to damage overall economic performance significantly. This would explain why Pellegrini and Gerlagh (2008) and Lederman et al. (2005) find the level of corruption to be lower, and Drury et al. (2006), its harm on economic growth to be less, in democratic countries.

It appears that voters react dramatically only when the corruption is massive, the information on it is highly-credible and well-publicized, involves large number of parties, not accompanied by otherwise competent and beneficial governance, and a non-corrupt alternative is available. According to Chang et al. (2010) that is exactly what happened in Italy in 1994. The election held in that year took place in the midst of the "Clean Hands" investigation which implicated more than a third of the legislators from different parties, including five former prime ministers and thousands of other politicians. A voter realignment of substantial proportions was the outcome. More than two-thirds of the incumbents did not make it to the new legislature. Almost all of the existing major parties collapsed and a new party system emerged. Ferraz and Finan (2008) provide yet another case of voter retaliation depending on the severity of corruption unearthed, its reliability and how well it is disseminated. They study the political consequences of municipal audits in Brazil as part of an anti-corruption program. This program involves audit of 50-60 cities each month, which are randomly selected by an open lottery. Then the appropriate prosecutors, city councils and the media are informed of the irregularities found. Ferraz and Finan find that the outcomes of these audits have significant effects on the reelection chances of mayors. The impact gets more pronounced when the level of corruption exposed is high and when this information is disseminated well.

Something very similar to the one which took place in Italy in 1994 occurred in Turkey eight years later, and much more drastically. In the election held on 3 November 2002, the voters ousted all of the parties which entered the parliament in the previous election, including the opposition parties. Nearly half of the electorate voted for brand new parties established shortly before the election. Only 11 percent of the legislators elected in 1999 made it to the 2002 parliament. Interestingly, the conditions listed by Chang et al. (2010), Manzetti and Wilson (2007) and Golden (2006) as necessary for such a dramatic voter reaction to occur, materialized before the 2002 election. Two major earthquakes in 1999 and a severe economic crisis in 2001 played crucial roles in that regard. The earthquakes which struck on 17 August 1999 and 12 November 1999 measured 7.4 and 7.2 on the Richter scale and hit densely populated and heavily industrialized northwestern section of the country (see Table 1 and Figure 1). Soon after, it became apparent that local politicians had been bribed into authorizing construction of buildings that violated construction and zoning codes. While a lot of the old buildings remained standing after the quakes, many of the recently constructed ones folded in on themselves due to their unsafe locations, inappropriate design, and substandard practices employed in their construction, such as use of concrete prepared with beach sand, insufficient amount of cement and steel bars. It was clear that far more people died and 
left homeless than need be the case. ${ }^{2}$ The opposition, and not the incumbent parties, were responsible for the corruption in question because the shoddy buildings were constructed during their time in office, and they controlled virtually all of the municipal administrations in the areas hit by the quakes, during the previous decade (see Table 2 and 3). ${ }^{3}$ Furthermore, these parties were already suspected of involvement in a number of other corruption cases during their rule. These largely went uninvestigated mainly due to their reluctance to remove the parliamentary immunities of their members. The governance under these parties was dismal as well. In half of the dozen years between 1988 and 1999, the growth rate of per capita GDP was negative. Probably that is why the only two parties not tried by the electorate for nearly two decades were brought to power in 1999, shortly before the earthquakes. However the latter too got tainted when corruption allegations were leveled against them involving post-quake relief and reconstruction efforts. Furthermore, the great amount of delay and incompetence they have exhibited in coming to the rescue of the quake survivors, their failure to prosecute corrupt officials and contractors--except for a token few--before the statute of limitations took effect, and their internal bickering which triggered the worst economic crisis to date in 2001, put them at par in governance with the rest of the parties, making the situation ripe for throw-the-rascals-out mood of the voters.

The purpose of our paper is to analyze the response of voters in the 2002 general election, the first one following the 1999 earthquakes, to the above events. In doing so, we hope to accomplish three goals. First, we would like to bring the case at hand to the attention of researchers investigating voter response to corruption, and to provide some supporting evidence for the assertions made by Chang et al. (2010), Manzetti and Wilson (2007), and Golden (2006). We think that this case has not received the attention it deserves, even in Turkey. Although quite a number of studies have cited governments' inability and reluctance to move against corruption in general, and even involvement in it, as a major contributing factor in the outcome of the 2002 election, the role played by the 1999 quakes in galvanizing the public is mostly overlooked. To the best of our knowledge, only Özel (2003), and Akarca (2010 and 2011) mention the earthquake factor, but do not measure its impact. ${ }^{4}$ Second, we would like to assess whether the Turkish voters have allocated the responsibility for various types of corruption and mismanagement, among various political parties, appropriately. In particular, we would like to determine whether the voters held previous governments which were in power

\footnotetext{
${ }^{2}$ Kinzer (2001) and Green (2005) explain in detail, how corruption magnified the above disasters in Turkey. Escalares, Anbarci and Register (2007), studying 344 major quakes in 42 countries during the 1975-2003 period, show that public sector corruption is positively related to earthquake fatalities in other countries as well.

${ }^{3}$ In Turkey, municipalities issue the permits for constructions and inspect them, but they are overseen by the central government. The latter by granting frequent amnesties for improperly and illegally constructed buildings, and providing utilities and other services to them, encourage their spread.

${ }^{4}$ Almost all of the studies on the 2002 election, for example Öniş (2006), Özel (2003), Önis and Keyman (2003), Çarkoğlu (2002) and Çağaptay (2002) argue, without any statistical estimation, that the 2001 economic crisis was one of the major causes of the spectacular vote losses experienced by the incumbent parties in 2002. Findings of Başlevent, Kirmanoğlu and Şenatalar (2005), who used rigorous statistical analysis, provide some statistical evidence in support of this view, but their study is based on a survey and not actual vote data. Furthermore, this survey was conducted before the election and before the establishment and entry of one of the new parties was announced.
} 
when the shoddy buildings were constructed, responsible as well, and whether they distinguished between the parties which controlled municipal administrations in the earthquake zone and those that did not. Third, we would like to model and measure interparty vote traffic between 1999 and 2002. This will help us understand the new party system which emerged as a result of it.

In the next section we will provide more detailed information about the events and political parties mentioned above. In section following that, we will explain the method and the data used in our analysis. In section 4, the empirical results will be presented, and finally in section 5, conclusions reached will be listed.

\section{Economic and political background}

The outcome of November 3, 2002 parliamentary election in Turkey was such a shock that journalists and academicians who analyze it often refer to it using terms such as landslide, meltdown, tsunami, and ironically, as earthquake. In that election, the aggregate vote share of the three incumbent parties, the Democratic Left Party (DSP), the Nationalist Action Party (MHP) and the Motherland Party (ANAP), dropped to 14.7 percent from 53.4 percent in the previous election held in April 18, 1999. ${ }^{5}$ The True Path Party (DYP), one of the opposition parties in the parliament, lost 2.5 of its 12 percent support in 1999. The closing of the main opposition Virtue Party (FP) by the Constitutional Court in 2001, forced 15.4 percent of the electorate which voted for this party in the previous election to make another choice in 2002. In short, in the 2002 election, nearly three out of five Turkish voters cast their ballots for a different party than they did in 1999. None of the parties which entered the parliament in 1999 were able to do so in 2002, failing to exceed the ten percent national threshold required to be represented in the Turkish Grand National Assembly. The combined vote share of the parties mentioned was 81 percent in 1999 but only 24 percent in $2002 .^{6}$

In hindsight, the building of voter dissatisfaction was quite visible. In each of the parliamentary elections since 1987, a different party finished first. Since 1991, each election produced a coalition government involving a different combination of parties. The voters were frustrated by the major accusations of corruption which went uninvestigated and at least one economic crisis under each party. However it took the earthquakes of 1999 and the economic crisis of 2001 to get the voters to react drastically. These added to the list of corruption-tainted and incompetent parties, the DSP and the MHP, the last remaining parties tried by the public.

The voters who migrated from the five political parties mentioned above moved essentially to one of the following three parties: the Justice and Development Party (AKP), the Republican People's Party (CHP) and the Young Party (GP). However, only the first two were able to muster enough votes to enter the new parliament. The AKP, one

\footnotetext{
${ }^{5}$ Percentages given in this section are in proportion to total valid votes cast.

${ }^{6}$ Of these parties, only the MHP was able to engineer a comeback. By 2011, the rest and the Young Party (GP), which emerged in 2002, disappeared either literally or for all practical purposes. Their combined vote share declined from $63 \%$ in 1999 to $23 \%$ in 2002 and to $2 \%$ in 2011.
} 
of the two parties to emerge from the banned FP, received the lion's share. Its vote share of 34.3 percent was more than twice that of the FP in 1999, indicating that it has attracted votes also from other parties. The Felicity Party (SP), the other party rooted in the FP however, received only 2.5 percent of the vote, perhaps due to towing the Islamist line of the old FP, unlike its rival AKP, which disavowed it. The CHP, which was left out of the parliament in 1999 due to falling below the ten percent mark then, was able to raise its proportion of the vote from 8.7 to 19.4 percent. However, the party's vote gain was about half the size of the votes lost by the other center-left party, the DSP. This hints that some of the vote traffic was from the parties on the left to the parties on the right. The GP, formed a few months before the 2002 election, by a young business tycoon, with no previous political experience, was the third magnet for the voters dissatisfied with the existing parties. It is remarkable that such a party, running on a populist and nationalistic platform, was able to get 7.2 percent of the votes, more than two of the incumbent parties and almost the same as the third one.?

The earthquakes provided us with a natural experiment, which we can use to determine how much penalty the voters levied for various kinds of corruption and mismanagement, as different group of parties were responsible for each. The DSP, the major incumbent party in 2002, came to power for the first time in June 1997 but got the premiership only seven months before the August 1999 earthquake. The party had no mayors in cities which suffered major damage in the quakes. Thus this party can only be held responsible for the inefficiency in providing relief and for its inability or unwillingness to prosecute corrupt officials and their private sector benefactors, but not for the corruption at the local level, and not for the construction of shoddy buildings.

The second largest incumbent party in 2002, the MHP, came to power less than three months before the first earthquake in 1999 and after being out of power for two decades. This party controlled only one small municipality in the area affected by the earthquakes. However, the minister of Public Works and Settlement, which supervises the General Directorate of Disaster Affairs, was from the party. He was accused after the 2002 election by the new government, of cronyism and receiving kickbacks from contractors his ministry employed to construct new housing for the earthquake survivors and for providing other relief efforts. Although he was found not guilty in 2007 by the Supreme Court, but it is doubtful that he is vindicated in the public opinion. Also, at the time of the 2002 election, whether he will be tried and how the verdict would turn out was not known. In fact, he was seen as a liability for his party and was forced to resign his post in 2001 by the leader of his party. Eight of his top bureaucrats and forty contractors they have collaborated with have been found guilty in 2008. Therefore any punishment of the party by voters should be attributed to its failure to come to the aid of the quake victims in a timely manner, failure to prosecute contractors who build the substandard structures and the officials who permitted it, and to involvement in corruption themselves. However it would not be rational for the voters to blame the MHP for the pre-quake corruption.

\footnotetext{
${ }^{7}$ The GP's success however turned out to be a flash in the pan. It disappeared from political scene after the 2007 election. The AKP and the CHP continued to raise their shares, the former to 49.8 percent and the latter to 26 percent by 2011
} 
The third incumbent party, the ANAP, held the premiership of the country in single-party governments between December 1983 and November 1991, and in coalition governments, during March 1996 - June 1996, and June 1997 -January 1999 periods. The party was a minor partner in the coalition ruling at the time of the 1999 earthquakes. It controlled substantial number of local administrations in the quake region since 1984 . Thus, as a party ruling both at national and local levels, and both before and after the quakes, the ANAP is the only party which can be held accountable for all aspects of corruption and mismanagement mentioned.

The opposition parties DYP and CHP were in power as partners during the 19911996 period and both had large number of mayors in the provinces affected by the two earthquakes during the decade preceding the quakes. ${ }^{8}$ Consequently they should share a large part of the blame for the shoddy buildings being built. The DYP leadership got entangled in a number of other corruption cases as well, which were never brought to trial. Most notable among them is the one which came to light inadvertently when a fatal car crash occurred near the small western town of Susurluk on 3 November 1996. In the car that ran into a truck were a senior police official, an assassin/drug dealer/gangster wanted by the police and Interpol, his ex-beauty queen girlfriend, and a Kurdish tribal leader/DYP parliament member (the wreck's sole survivor). The car's trunk held an array of pistols and silencers, plus official documents establishing several false identities for the fugitive criminal apparently provided by the former Director General of the Turkish Police, who was minister of Justice at the time. The DYP leader owned up to her government's actions, invoking national security. She herself was accused of illegally enriching her family shortly before that incident. Then her party was a partner in another coalition government with the ANAP. When the ANAP deputies decided to vote in favor of lifting her parliamentary immunity so that she can be tried, she accused them of partisanship and pulled her party out of the coalition and formed another government with the RP which agreed to reject the motion to remove her immunity.

If the voters are rational, the GP should either be unaffected by the earthquake related events, or benefit from them, as this party was formed only a few months before the 2002 election.

The AKP is one of the two parties to rise out of the ashes of the banned FP, in the second half of 2001, after the dissolution of the latter by the Constitutional Court on grounds that it violated the secularism clause of the constitution. The FP itself was formed by the leaders and rank and file of the Welfare Party (RP) which was closed by the Constitutional Court on the same grounds used against the FP. While the RP held power only for a year from mid-1996 to mid-1997, many of the mayors in the provinces affected by the 1999 quakes were members of this party since 1994. The AKP disavowed the anti-Western and pro-Islamist positions of the FP and rejected being a

\footnotetext{
${ }^{8}$ We are treating the CHP and the Social Democratic Populist Party (SHP) as one party. Between November 1991 and February 1995 the SHP was in power with DYP. This party joined the CHP in February 1995. Then the coalition government continued until March 1996 with the latter party as the official partner.
} 
continuation of the FP or RP. The Felicity Party (SP), the other party rooted in the FP, towed the old party line and received very few votes in 2002. If the AKP is not viewed by the public as a continuation of the RP, or if the mayors elected under the RP banner -many of which later joined the AKP-- were not viewed as being corrupt, the AKP should benefit from poor and corrupt performance of other parties in office.

\section{Data and method}

Our analysis is based on vote equations estimated for each major political party: AKP, ANAP, CHP, DSP, DYP, GP, and MHP. We measured the vote shares of the parties as a proportion of registered voters, not of legitimate votes cast. This was done to check whether voters used not voting as a vehicle to respond. ${ }^{9}$ The group of people who registered but did not vote is treated as if they constitute another party, which we labeled as NV. Thus one of the equations estimated is for the NV.

The equations in question are fitted to cross-provincial data. However 20 of the 81 provinces are excluded from the sample. 16 of these are the provinces in which the Kurdish-nationalist Democratic People's Party (DEHAP) has received more than 10 percent of the vote in 2002. These are all in the eastern and south-eastern sections of the country, far from the area where the quakes took place. The behavior of voters in these provinces is considerably different than in the rest of the country. It is largely ethnic based and is affected a lot by the Kurdish insurgency in the region and the government's response to it. The proportion of votes received by the Kurdish-nationalist parties, the People's Democracy Party (HADEP) in 1999 and the Democratic People's Party (DEHAP) in 2002, in this region was about ten times their vote share in the rest of the country. While the ANAP and DYP managed to get about the same proportion of votes there as in the rest of the country, the vote shares of the MHP, AKP, and GP were 35-80 percent lower. Also, the proportion of votes cast for independent candidates in the region was 7-10 times higher than the corresponding figure in the remaining provinces. Most of these independent candidates were either tribal leaders or members of parties which were not expected to surpass the ten percent nationwide threshold. In short, different dynamics were at play in the 16 provinces excluded.

Also excluded from the sample are the following four provinces: Rize, Osmaniye, Bayburt and Bartın. The first two of these are the home provinces of the leaders of the ANAP and MHP, where their candidacies bring to their parties substantially more votes than would be the case if they were not running. In the third, an independent candidate received more than a fourth of the vote. ${ }^{10}$ The last province is one of the only two provinces in the country in which the MHP was able to raise its vote shares between 1999 and 2002. We could have excluded, under the same criteria, Sakarya and Yalova as well.

\footnotetext{
${ }^{9}$ Chong et al. (2011), analyzing Mexican data, show that exposing rampant corruption leads not only to incumbents' vote loses, but also to a decrease in electoral turn-out and a decrease in challengers' votes.

${ }^{10}$ In 2002 election, substantial amount votes went to an independent candidate in Elazı g and to a minor regional party in Sivas as well, but elimination of these observations is not considered because that was the case in 1999 as well.
} 
The former is the home province of the GP leader where he was the favorite son. ${ }^{11}$ The latter is the other exceptional province in which the MHP was able to raise its vote share. ${ }^{12}$ However excluding these two provinces from the sample would be like throwing the baby with the bath water, as they are two of the provinces affected by the quakes. Instead we handled these cases by adding two dummy variables in the equations.

The provinces that are included and excluded from the sample are shown in Figure 1, and the sources of data are given in the notes to tables 1, 4, and 5 .

Our equations take the following form:

$$
\begin{gathered}
\mathrm{V}_{\mathrm{ijt}}=\mathrm{a}_{\mathrm{i}}+\sum_{k=1}^{l} \mathrm{~b}_{\mathrm{ik}} \mathrm{V}_{\mathrm{kjt}-4}+\mathrm{c}_{\mathrm{i}} \mathrm{S}_{\mathrm{jt}}+\mathrm{d}_{\mathrm{i}} \mathrm{U}_{\mathrm{jt}}+\mathrm{f}_{\mathrm{i}} \mathrm{W}_{\mathrm{jt}}+\mathrm{h}_{\mathrm{i}} \mathrm{Q}_{\mathrm{jt}-3}+\sum_{k=1}^{2} \mathrm{~m}_{\mathrm{ik}} \mathrm{D}_{\mathrm{kjt}}+\mathrm{e}_{\mathrm{ijt}} \\
\mathrm{i}=1,2, \ldots \ldots \mathrm{l} \text { and } \mathrm{j}=1,2, \ldots, \mathrm{n}
\end{gathered}
$$

in which the variables in it are defined as follows:

1 : the number of major parties participating in the election plus one (registered voters who chose not to vote)

$\mathrm{n} \quad$ : the number of provinces

$\mathrm{V}_{\mathrm{ijt}}$ : the vote share of party $\mathrm{i}$, in province $\mathrm{j}$, in the election held in year $\mathrm{t}$

$\mathrm{V}_{\mathrm{ijt}-4}$ : the vote share of party $\mathrm{i}$, in province $\mathrm{j}$, in the previous election held approximately four years earlier

$S_{\mathrm{jt}}$ : mean years of schooling of the population over age 6 , in province $\mathrm{j}$, in year $\mathrm{t}$

$\mathrm{U}_{\mathrm{jt}}$ : proportion of urban population in province $\mathrm{j}$, in year $\mathrm{t}$

$\mathrm{W}_{\mathrm{jt}}$ : proportion of women in the non-agricultural employment in province $\mathrm{j}$, in year $\mathrm{t}$

$\mathrm{Q}_{\mathrm{jt}-3}$ : number of residences and places of business that suffered heavy damage (per hundred people) in province j, during the earthquakes of 17 August 1999 and 12 November 1999

$D_{\mathrm{kjt}}$ : dummy variable which takes on the value of 1 for the province $\mathrm{k}$ and zero for all others

$e_{i j t}:$ the disturbance term for party $i$, in province $j$, in year $t$

\footnotetext{
${ }^{11}$ Party leaders other than ANAP, MHP, GP and AKP did not have such a strong identification with any particular province.

${ }^{12}$ This was as a result of a prominent ANAP politician from Yalova, urging his supporters to vote for the MHP in 2002.
} 
$\left\{\mathrm{a}_{\mathrm{i}}\right\},\left\{\mathrm{b}_{\mathrm{ik}}\right\},\left\{\mathrm{c}_{\mathrm{i}}\right\},\left\{\mathrm{d}_{\mathrm{i}}\right\},\left\{\mathrm{f}_{\mathrm{i}}\right\},\left\{\mathrm{h}_{\mathrm{i}}\right\}$, and $\left\{\mathrm{m}_{\mathrm{ik}}\right\}$ are parameters. $\left\{\mathrm{V}_{\mathrm{ijt}}\right\},\left\{\mathrm{V}_{\mathrm{ijt}-4}\right\},\left\{\mathrm{U}_{\mathrm{jt}}\right\}$ and $\left\{\mathrm{W}_{\mathrm{jt}}\right\}$ are measured in percentage points. For the provinces listed in table 1 , the $\mathrm{Q}$ variable is equal to the figures given in the table multiplied by 100 , and for the rest of the provinces, it is equal to zero.

Each party's previous vote share appears in its vote equation as an independent variable. The coefficients of these variables will allow us to measure what proportion of their previous supporters they were able to keep. Votes of incumbent parties are expected to erode. According to economic voting literature, it is almost inevitable for parties in power not to disappoint some of their supporters with their compromises, unpopular decisions, and the mistakes they make, especially if the economic conditions are not good either. Also, a portion of the electorate votes strategically against the incumbents to balance their power. ${ }^{13}$ Political parties tainted by corruption and incompetence are likely to lose some of their supporters as well. Presumably, these will flow to new parties and old parties, which are not known for their bad governance and corrupt behavior. To capture such flows, the lagged vote shares of other parties are included in each party's equation. The parties whose 1999 vote shares enter the equations as independent variables are the following: ANAP, CHP, DSP, DYP, FP and MHP.

It is not feasible to have lagged vote shares of all parties on the right hand sides of each equation, as this will lead to multi-colinearity. Consequently some of them need to be excluded. Fortunately, the vote share of the CHP either increased or essentially remained the same between 1999 and 2002 in every province in our sample. Its 1999 vote share was unusually low by historical standards anyway, which resulted in the party being left out of the parliament. Similarly, the Justice and Development Party (AKP), not only received more votes than the Virtue Party (FP) in total, but its vote share was substantially higher than that of the party from which it emerged, in every single province in the sample as well. The Felicity Party (SP), the other party to emerge out of the Virtue Party (FP), received only a negligible amount of the votes, as mentioned in the previous section. Thus the 1999 vote share of the CHP can be eliminated from all equations except its own, and the 1999 FP vote share can be eliminated from all equations except that of the AKP. Furthermore, since the ANAP and DSP lost votes in all provinces in the sample, and the MHP in all, except one (for which a dummy variable is used), we can eliminate the lagged vote shares of other parties from their equations. Since the participation rate in 2002 was much lower than in 1999, the lagged value of NV appear only in the NV equation.

No data exists on government's response time to the earthquake disasters, on the number of buildings damaged due to poor construction, and on when these were constructed. Neither is there any information on how many corrupt officials and contractors are let go because only a few of them were even charged. However it is reasonable to assume that the people living in the nine provinces affected by the 1999 earthquakes would have more information on these than the general public.

\footnotetext{
${ }^{13}$ For a survey of economic voting literature, see Lewis-Beck and Paldam (2000), Lewis-Beck and Stegmaier (2000, 2007 and 2008), and Akarca and Tansel (2006 and 2007).
} 
Consequently, the tendency to vote against the parties involved in corruption and mismanagement would be more pronounced in these provinces and by measuring it, we can get a better idea as to which parties were held accountable by the more informed people. Presumably, the greater is the number of residences and businesses which suffered heavy damage in a province, the greater is the information each voter in that province is exposed to on the level of corruption involved and on the quality of the relief provided by the government. Thus the estimated parameter of the $\mathrm{Q}$ variable included in each equation can be viewed as the incremental response of the voters who are more knowledgeable and affected by the government corruption and incompetence.

Socio-economic indicators are included in the equations to control for local conditions. Economic interests and ideologies of voters depend on whether they are educated or not, and whether they live in an urban or a rural location. S and U are included in the vote equations to capture the impact of these two factors on the vote shares of various political parties. W is considered as a proxy for the degree of conservatism and/or religiosity of the voters in a province. Highly conservative and devoutly religious families in Turkey tend to oppose female members of their families to work outside the home, unless it is with other family members in an agricultural setting. Thus we thought that the proportion of women in non-agricultural employment in a province would be a good indicator of the proportion of voters in that province who can be categorized as conservative/religious.

\section{Empirical results}

Regressions relating 2002 vote shares of major political parties to the variables mentioned in the previous section are presented in tables 4 and 5. In these tables the 2002 vote shares of the AKP, CHP, GP, DSP, MHP, ANAP, DYP and those not voted are represented by the symbols: AKP2002, CHP2002, GP2002, DSP2002, MHP2002, ANAP2002, DYP2002 and NV2002, respectively. Similarly, the 1999 vote shares of the FP, CHP, DSP, MHP, ANAP, DYP and those not voted are represented by the symbols: FP1999, CHP1999, DSP1999, MHP1999, ANAP1999, DYP1999 and NV1999, respectively. The symbols $\mathrm{S}, \mathrm{U}$, and $\mathrm{W}$ are used to represent the mean years of schooling, the urbanization rate, and the proportion of women in non-agricultural employment, respectively. Q stands for the number of residences and businesses which suffered heavy damage in the 1999 earthquakes, per hundred people. Province names are used to represent the dummy variables, which take the value of one for the named province and zero for all others. All of the zero-parameter restrictions mentioned in the previous section are applied. If in the preliminary estimation the parameter of a dummy variable turned out to be small or insignificant in any equation, it is eliminated from that equation.

Table 4 presents the Ordinary Least Squares (OLS) estimates. Equations with dummy variables are presented with and without the dummy variables so that their importance is realized. For example, introduction of the SAKARYA dummy in the GP equation causes the parameter of the $\mathrm{Q}$ variable to become much smaller and statistically 
insignificant. On the other hand, introduction of the YALOVA dummy in the MHP equation changes the $\mathrm{Q}$ variable's parameter from being highly insignificant to being highly significant. Despite our efforts to deal with outliers through exclusion of provinces with special circumstances from the sample, use of dummy variables and socio-economic control factors, in a case like the one at hand, where special circumstances at the local level can make a big difference, we cannot be certain that all outliers are fully taken care of. To make sure that the OLS estimates are not driven by a few outliers, we estimated the equations also using the robust regression technique. The results of that are given in table 5. Indeed a number of additional outliers are detected which are listed in the notes of table 5 .

Most of the estimated coefficients in tables 4 and 5 are quite similar but a few differ notably in magnitude. ${ }^{14}$ However the picture emerging from each table is essentially the same. Between 1999 and 2002 elections, there was a general shift in votes, from the extreme right MHP and the center- right ANAP and DYP towards the $\mathrm{AKP}$, as indicated by the coefficients of the lagged vote variables. This was even more pronounced in provinces which suffered heavy earthquake damage, as indicated by the coefficients of the $\mathrm{Q}$ variable in various vote equations. In the latter provinces there was a shift in votes towards the AKP from the center-left CHP and DSP as well. It appears that the AKP was either not seen by voters as the continuation of the Welfare and Virtue parties, or that the mayors of the latter were not seen as corrupt. ${ }^{15}$ Although the voter turn-out was lower in 2002 than in 1999, which can be taken as an indication of voter disillusionment with the political process, there is no indication that voter participation in the provinces hit by the earthquakes was any different than the rest of the country. If anything, there is a suggestion in table 4 that participation has increased, but that disappears in robust regressions. Countrywide, there is a hint that proportion of those who chose not to vote was slightly higher among ANAP supporters, and slightly lower among the DYP supporters.

For the three incumbent parties, the DSP, MHP and ANAP, the estimated coefficients of their own lagged vote variables imply that in a typical province they have lost almost all, three-fourths, and three to four-fifths, of their 1999 votes, respectively, controlling for other factors. These are far more than the usual amounts of erosion that can be expected in the vote shares of incumbent parties due to controversial decisions they make while in office, due to voter efforts to create checks and balances against their power, and economic performance. These losses no doubt reflect to a large extent the disappointment of their supporters all over the country, with the way they have responded to the earthquakes, with their failure to stop or prosecute culprits of earthquake related corruption, and with their poor governance. Interestingly, the harshest punishment was levied against the prime-minister's party, the DSP, despite his non-corrupt personal

\footnotetext{
${ }^{14} \mathrm{We}$ have also estimated the equations as a system of seemingly unrelated regressions (SUR). The resulting estimates were very close to the OLS estimates. For brevity we are not presenting the SUR results.

${ }^{15}$ Henderson and Kuncoro (2011) finds that in Indonesia, Islamic parties at the local level seem to have credibility in voters' minds, perhaps based on the perceived personal integrity of their candidates. The same may have been the case with the Islamist RP.
} 
image and the ministry responsible for disaster relief being in another party's portfolio. The DSP disappeared in 2002, for all practical purposes. According to the parameter estimates of DSP1999 in various vote equations, more than half of the party's supporters deserted it for the CHP and GP, and about a fifth of them moved to the DYP. Besides the poor governance under the leadership of the party in the aftermath of the earthquakes, it triggering the 2001 crisis no doubt has contributed to this outcome.

The fact that the DYP, an opposition party in 2002, lost supporters --about a third of them-- perhaps can be interpreted as payment for its past involvement in corruption, some of which was discussed in section 2. It was collected by the electorate when the conditions ripened, meaning when the other parties begun being judged by their supporters. However these losses were offset, at least partially and for a while, by about a fifth of ANAP and a fifth of DSP voters changing their allegiances to the DYP.

Both, parties in power and in opposition, suffered additional vote losses in the quake-affected provinces. This represents the response of those who possess more information than the general public on who to blame for the poorly constructed buildings which collapsed, and for the poor and corruption-tainted relief efforts. Among the incumbent parties, the MHP paid the highest price. Even though the party controlled virtually no municipalities in the area, it was responsible for providing relief. Thus its punishment can be attributed to its poor and corrupt performance in providing relief. ${ }^{16}$ Interestingly, the DSP, which had no mayors in the quake-ravaged cities, and was not directly involved with disaster relief, suffered only a negligible amount of extra loss. The fact that three parties which controlled the local administrations in the area, the ANAP, DYP and CHP were all dealt relatively high doses of punishment indicates that contributing in the past to the construction of defective buildings and profiting from that, angered the voters as well. Because there are no parties which controlled local governments but not served in central government, we are unable to assess relative blame placed by voters on the central and local governments. A survey conducted by Adaman and Çarkoğlu (2001) however show that, in general, urban dwellers in Turkey, perceive central and local governments to be both corrupt but the central government to be more corrupt. Our results here do not contradict that.

An analysis of the coefficients of the dummy variables reveal that votes gained by the MHP in Yalova and by the GP in Sakarya, due to circumstances discussed above, came largely at the expense of the AKP.

\section{Conclusions}

A few studies in corruption literature suggest that politicians pay a significant price for corruption, only when the corruption is massive, the information on it is highlycredible and well-publicized, involves all parties across the board, and not accompanied

\footnotetext{
${ }^{16}$ In a recent paper, Cole et al. (2012) find that in India, fewer voters punish a ruling party when it responds vigorously to a disaster. The Turkish case complements this by showing that voters punish incumbents responsible for relief more when their efforts are lacking.
} 
by good governance. Such conditions came together before the voters ousted all of the parties from the parliament in Turkey in 2002. In hindsight, it appears that during the two decades preceding the 2002 election, Turkish voters tried one-by-one all of the parties in the parliament, either individually or in groups. After experiencing bad governance and corruption under each, they gradually deserted them. Only after all of the established parties got implicated by corruption and poor governance, including the last two that were tried, they reacted dramatically. We have shown that the corruption related to the 1999 earthquakes and emergence of a new viable party as an alternative, played crucial roles in that.

Our findings suggest that, in casting their ballots in 2002, the Turkish voters have taken into account the performance of all governments that contributed to the magnification of the earthquake disasters. Not just the incumbent parties at the time of the earthquakes but also others which were in power when the substandard buildings were built were held accountable. Furthermore, the Turkish voters appear to have allocated the blame rationally, taking into consideration the division of labor in the central government, and the relative influence the parties had on local administrations.

Reaction of the voters to government incompetence and corruption resulted in the emergence of a new party system. In 2002 elections more than half of the voters cast their ballots for a different party than the one they chose in 1999. Two new parties, formed shortly before the election received more than two fifths of the votes. Another party, which was left outside the parliament during 1999-2002, received about a fifth of the votes, more than doubling its share in the previous election. Votes moved from the Virtue, Nationalist Action, Motherland and True Path parties (FP, MHP, ANAP and DYP) to the Justice and Development Party (AKP), from the Democratic Left Party (DSP) to the Republican People's, True Path and Young parties (CHP, DYP and GP), and from the Democratic Left and Motherland parties (DSP and ANAP) to the True Path Party (DYP). Looking from another vantage point, the Justice and Development Party (AKP), ruling since 2002, captured almost all of the far-right Islamist, about half of the far-right nationalist, and more than half of the center-right votes in 2002.

\section{6. $\quad$ References}

Adaman, F. and Çarkoğlu, A. 2001. "Perceptions of Central and Local Governments' Engagement in Corruptive Activities: The Case of Turkey," Working Paper No. 0103, Economic Research Forum (ERF), Cairo, Egypt.

Adserà, A., Boix, C. and Payne, M. 2003. "Are You Being Served? Political Accountability and Governmental Performance," Journal of Law, Economics and Organization, Vol. 19, pp. 445-490.

Akarca, A. T. 2011. "A Prediction for AKP's Nationwide Vote Share in the 12 June 2011 Turkish Parliamentary Election," İktisat İşletme ve Finans, Vol. 26, No. 302, pp. 53-74. 
Akarca, A. T. 2010. "Analysis of the 2009 Turkish Election Results from an Economic Voting Perspective," European Research Studies Journal, Vo. 13, No. 3, pp. 3-38.

Akarca, A. T. and Tansel, A. 2007. "Social and Economic Determinants of Turkish Voter Choice in the 1995 Parliamentary Election," Electoral Studies, Vol. 26, pp. 633-647.

Akarca, A. T. and Tansel, A. 2006. "Economic Performance and Political Outcomes: An Analysis of the Turkish Parliamentary and Local Election Results Between 1950 and 2004," Public Choice, Vol. 129, pp. 77-105.

Alesina, A and Weder, B. 2002. "Do Corrupt Governments Receive Less Foreign Aid?" American Economic Review, Vol. 92, pp. 1126-1137.

Anbarci, N., Escalares, M. and Register, C. 2006. "Traffic Fatalities and Public Sector Corruption," Kyklos, Vol. 59, pp. 327-344.

Başlevent, C., Kirmanoğlu, H. and Şenatalar, B. 2005. "Empirical Investigation of Party Preferences and Economic Voting in Turkey," European Journal of Political Research, Vol. 44, pp. 547-562.

Besley, T. and Burgess, R. 2002. "The Political Economy of Government Responsiveness: Theory and Evidence from India," Quarterly Journal of Economics, Vol. 117, pp. 1415-1451.

Brunetti, A. and Weder, B. 2003. "A Free Press Is Bad News for Corruption," Journal of Public Economics, Vol 87, pp. 1801-1824.

Carden, A. and Verdon, L. 2010. "When is Corruption a Substitute for Economic Freedom?" The Law and Development Review, Vol. 3, pp. 41-64.

Chang, E. C. C., Golden, M. A. and Hill, S. J. 2010. "Legislative Malfeasance and Political Accountability," World Politics, Vol. 62, pp. 177-220.

Chong, A., De La O, A. L., Karlan, D. and Wantchekon, L. 2011. "Looking Beyond the Incumbent: The Effects of Exposing Corruption on Electoral Outcomes," Working Paper No. 17679, National Bureau of Economic Research (NBER), Cambridge, Massachusetts.

Cole, S., Healy A., and Werker, E. 2012. "Do Voters Demand Responsive Governments? Evidence from Indian Disaster Relief," Journal of Development Economics, Vol. 97, pp. 167-181.

Costas, E, Solé-Ollé, A. and Sorribas-Navarro, P. 2011. "Corruption Scandals, Press Reporting, and Accountability: Evidence from Spanish Mayors," Working Paper No. 2011/9, Institut d'Economia de Barcelona, Barcelona, Spain. 
Çağaptay, S. 2002. "The November 2002 Elections and Turkey's New Political Era," Middle East Review of International Affairs, Vol. 6, pp. 42-48.

Çarkoğlu, A. 2002. “Turkey's November 2002. Elections: A New Beginning?” Middle East Review of International Affairs, Vol. 6, pp. 30-41.

Dimock, M. A. and Jacobson, G. C. 1995. "Checks and Choices: The House Bank Scandal's Impact on Voters in 1992." Journal of Politics, Vol. 57, pp. 1143-1159.

Drury, A. C., Krieckhaus, J. and Lusztig, M. 2006. "Corruption, Democracy and Economic Growth,” International Political Science Review, Vol. 27, pp. 121-136.

Escaleras, M., Lin, S. and Register, C. 2010. "Freedom of Information Acts and Public Sector Corruption," Public Choice, Vol. 145, pp. 435-460.

Escaleras, M., Anbarci, N. and Register C. A. 2007. "Public Sector Corruption and Major Earthquakes: A Potential Deadly Interaction," Public Choice, Vol. 132, pp. 209-230.

Fernández-Vázquez, P. and Rivero, G. 2011. "Electoral Consequences of Corruption Charges in Andalucia (Spain), 2003-2007," unpublished manuscript.

Ferraz, C. and Finan, F. 2008. "Exposing Corrupt Politicians: The Effect of Brazil's Publicly Released Audits on Electoral Outcomes," Quarterly Journal of Economics, Vol. 123, pp. 703-745.

Freille, S., M., Haque, E. and Kneller, R. 2007. "A Contribution to the Empirics of Press Freedom and Corruption." European Journal of Political Economy, Vol. 23, pp. 838862.

Gentzkow, M., Glaeser, E. L. and Goldin, C. 2004. "The Rise of the Fourth Estate: How Newspapers Became Informative and Why It Mattered," in Glaeser, E. L. and Goldin, C. (eds.), Corruption and Reform: Lessons from America's Economic History, Chicago: University of Chicago Press.

Golden, M. A, 2006. "Some Puzzles of Political Corruption in Modern Advanced Democracies," paper presented at the annual meeting of the Japan Political Science Association, 29 December 2006, Tokyo, Japan (http://www.golden.polisci.ucla.edu/).

Green, P. 2005. "Disaster by Design: Corruption, Construction and Catastrophe," British Journal of Criminology, Vol. 45, pp. 528-546.

Habib, M. and Zurawicki, L. 2002. "Corruption and Direct Foreign Investment," Journal of International Business Studies, Vol. 33, pp. 291-307. 
Henderson, J. V. and Kuncoro, A. 2011. "Corruption and Local Democratization in Indonesia: The Role of Islamic Parties," Journal of Development Economics, Vol. 94, pp. $164-180$.

Johnson, N. D., LaFountain, C. L. and Yamarik, S. 2011. "Corruption is Bad for Growth (Even in the United States)," Public Choice, Vol. 147, pp. 377-393.

Kaufman, D. and Wei, C. S. 2000. "Does Grease Money Speed up the Wheels of Commerce?" Working Paper No. 00/64, International Monetary Fund, Washington, D.C.

Kinzer, S. 2001. “Turkey's Political Earthquake," Middle East Quarterly, Vol 20, pp. 41-48.

Lederman, D. Loayza, N. V. and Soares, R. R. 2005. "Accountability and Corruption: Political Institutions Matter," Economics and Politics, Vol. 17, pp. 1-35.

Leff, N. 1964. "Economic Development Through Bureaucratic Corruption," American Behavioral Scientist, Vol. 8, pp. 8-14.

Lewis-Beck, M. S. and Paldam, M. 2000. "Economic Voting: An Introduction," Electoral Studies, Vol. 19, pp. 113-121.

Lewis-Beck, M. S. and Stegmaier, M. 2008. "The Economic Vote in Transitional Democracies," Journal of Elections, Public Opinion and Parties, Vol. 18, No. 3, pp. 303-323.

Lewis-Beck, M. S. and Stegmaier, M. 2007. "Economic Models of Voting”, in: R. Dalton and H. Klingemann (eds), The Oxford Handbook of Political Behavior, Oxford: Oxford University Press, pp. 518-537.

Lewis-Beck, M. S. and Stegmaier, M. 2000. "Economic Determinants of Electoral Outcomes," Annual Review of Political Science, Vol. 3, pp. 183-219.

Manzetti, L. and Wilson, C. J. 2007. "Why Do Corrupt Governments Maintain Public Support?" Comparative Political Studies, Vol. 40, No. 8, pp. 949-970.

Mauro, P. 1997. "The Effects of Corruption on Growth, Investment and Government Expenditure: A Cross-country Analysis," in Elliot, K. A. (ed.), Corruption and Global Economy, Institute for International Economics: Washington, D.C.

Mauro, P. 1995. "Corruption and Growth," Quarterly Journal of Economics, Vol. 110, pp. 681-712.

Méon, P. and Sekkat, K. 2005. "Does Corruption Grease or Sand the Wheels of Growth," Public Choice, Vol. 122, pp. 69-97. 
Mo, P. 2001. "Corruption and Economic Growth," Journal of Comparative Economics, Vol. 29, pp. 66-79.

Murphy, K., Shleifer, A. and Vishny, R. 1993. "Why is Rent-seeking So Costly to Growth?" American Economic Review, Vol. 83, pp. 409-414.

Murphy, K., Shleifer, A. and Vishny, R. 1991. "The Allocation of Talent: Implications for Growth," Quarterly Journal of Economics, Vol. 106, pp. 503-530.

Nye, J. S. 1989. "Corruption and Political Development: A Cost Benefit Analysis," American Political Science Review, Vol. 61, 417-427.

Öniş, Z. 2006. "Globalization and Party Transformation: Turkey's Justice and Development Party in Perspective," in P. Burnell (ed.), Globalizing Democracy: Party Politics in Emerging Democracies, London: Routledge.

Öniş, Z. and Keyman, E. F. 2003. “A New Path Emerges,” Journal of Democracy, Vol. 14, pp. 95-107.

Özel, S. 2003. "Turkey at the Polls: After the Tsunami," Journal of Democracy, Vol. 14, pp. 80-94.

Özmen, B. 2000a. "17 Ağustos 1999 İzmit Körfezi Depreminin Hasar Durumu (Rakamsal Verilerle)" (Damage Caused by 17 August 1999 Gulf of İzmit Earthquake: Quantitative Data), report number TDV/DR 010-53, Türkiye Deprem Vakfi, Ankara.

Özmen, B. 2000b. "12 Kasım 1999 Düzce Depreminin Konut ve İşyeri Hasarları (Rakamsal Verilerle)," (Residential and Commercial Building Damages Caused by 12 November 1999 Düzce Earthquake), in Özmen, B. and Bağc1 B. (eds), 12 Kasım Düzce Depremi Raporu (Report on 12 November 1999 Düzce Earthquake), Ankara: Bayındırlık ve İskan Bakanlığı, Afet İşleri Genel Müdürlüğü, Deprem Araştırma Dairesi, pp. 155214.

Pellegrini, L. and Gerlagh, R. 2008. "Causes of Corruption: A Survey of Cross-country Analyses and Extended Results," Economics of Governance, Vol. 9, pp. 245-263.

Pellegrini, L. and Gerlagh, R. 2004. "Corruption Effects on Growth and Its Transmission Channels,” Kyklos, Vol. 57, pp. 429-456.

Peters, J. G. and Welch, S. 1980. "The Effects of Charges of Corruption on Voting Behavior in Congressional Elections," American Political Science Review, Vol. 74, pp. 697-708.

Reed, S. R. 2005. "Japan: Haltingly toward a Two-Party System," in Gallagher, M. and Mitchell, P. (eds.), The Politics of Electoral Systems, Oxford: Oxford University Press. 
Rose-Ackerman, S. (1997). "The Political Economy of Corruption," in K. A. Elliot (ed.), Corruption and the Global economy, Washington: Institute for International Economics, pp. 133-145.

Rousseeuw, P.J. 1984. "Least Median of Squares Regression," Journal of the American Statistical Association, Vol. 79, pp. 871-880.

Rousseeuw, P.J. and Van Driessen, K. 2000. "An Algorithm for Positive-Breakdown Regression Based on Concentration Steps," in W. Gaul, O. Opitz, and M. Schader (eds.), Data Analysis: Scientific Modeling and Practical Application, New York: SpringerVerlag, pp. 335-346.

SAS. 2008. SAS/STAT 9.2 User's Guide. Cary, North Carolina: SAS Institute Inc.

Swaleheen, M. 2011. "Economic Growth with Endogenous Corruption: An Empirical Study," Public Choice, Vol. 146, pp. 23-41.

Tanzi, V. and Davoodi, H. 1997. "Corruption, Public Investment and Growth," Working Paper No. 97/139, International Monetary Fund, Washington, D.C.

Welch, S. and Hibbing, J. R. 1997. "The Effects of Charges of Corruption on Voting Behavior in Congressional Elections, 1982-1990," Journal of Politics, Vol. 59, pp. 226239.

Zaman, A., Rousseeuw, P.J. and Orhan, M. 2001. "Econometric Applications of HighBreakdown Robust Regression Techniques," Econometrics Letters, Vol. 71, pp. 1-8. 
Table 1:

Property damage caused by the 1999 earthquakes

\begin{tabular}{|l|c|c|}
\hline \multirow{2}{*}{ PROVINCES } & \multicolumn{2}{|c|}{ Residences and businesses with heavy damage } \\
\cline { 2 - 3 } & Total & Per ten thousand people \\
\hline Bolu & 2750 & 101.61 \\
\hline Bursa & 128 & 0.60 \\
\hline Düzce & 15134 & 481.57 \\
\hline Eskişehir & 111 & 1.57 \\
\hline İstanbul & 3306 & 3.30 \\
\hline Kocaeli & 41041 & 340.28 \\
\hline Sakarya & 29701 & 392.78 \\
\hline Yalova & 14473 & 858.46 \\
\hline Zonguldak & 114 & 1.85 \\
\hline
\end{tabular}

Table 1 notes:

In 1999 the administrative division of the country was slightly different. The table is based on the structure prevailing in 2002.

Source:

Figures on the first column are provided by the General Directorate of Disaster Affairs (Ministry of Public Works and Settlement, the Republic of Turkey) and reflects the most recent revision dated 22 April 2003. The second column is obtained by dividing the figures in the first column by the province's 2000 population given by the Turkish Statistical Institute (Prime Ministry, the Republic of Turkey) and then multiplying by 10,000. 
Table 2:

The ruling parties between 1983 and 2002

\begin{tabular}{|c|c|c|c|}
\hline POLITICAL PARTIES & PERIODS & $\begin{array}{l}\text { PRIME } \\
\text { MINISTER } \\
\text { FROM THE } \\
\text { PARTY? }\end{array}$ & $\begin{array}{c}\text { COALITION } \\
\text { GOVERNMENT? }\end{array}$ \\
\hline Motherland Party (ANAP) & $\begin{array}{l}\text { Dec. } 1983 \text { - Nov. } 1991 \\
\text { Mar. } 1996 \text { - June } 1996 \\
\text { June } 1997 \text { - Jan. } 1999 \\
\text { May } 1999 \text { - Nov. } 2002\end{array}$ & $\begin{array}{l}\text { YES } \\
\text { YES } \\
\text { YES } \\
\text { NO }\end{array}$ & $\begin{array}{l}\text { NO } \\
\text { YES } \\
\text { YES } \\
\text { YES }\end{array}$ \\
\hline True Path Party (DYP) & $\begin{array}{l}\text { Nov. } 1991 \text { - Mar. } 1996 \\
\text { Mar. } 1996 \text { - June } 1997\end{array}$ & $\begin{array}{l}\text { YES } \\
\text { NO }\end{array}$ & $\begin{array}{l}\text { YES } \\
\text { YES }\end{array}$ \\
\hline $\begin{array}{l}\text { Republican People's Party (CHP) / } \\
\text { Social Democratic Populist Party (SHP) }\end{array}$ & Nov. 1991 - Mar. 1996 & NO & YES \\
\hline Welfare Party (RP) & June 1996 - June 1997 & YES & YES \\
\hline Democratic Left Party (DSP) & $\begin{array}{l}\text { June } 1997 \text { - Jan. } 1999 \\
\text { Jan. } 1999 \text { - Nov. } 2002\end{array}$ & $\begin{array}{l}\text { NO } \\
\text { YES }\end{array}$ & $\begin{array}{l}\text { YES } \\
\text { YES }\end{array}$ \\
\hline Nationalist Action Party (MHP) & May 1999 - Nov. 2002 & NO & YES \\
\hline
\end{tabular}

Table 2 notes:

In paranthesis are the Turkish acronyms of political parties. Between November 1991 and February 1995 the Social Democratic Populist Party (SHP) was one of the two parties in power. This party joined the Republican People's Party (CHP) in February 1995. Then the coalition government continued until March 1996 with the latter party as the official partner. The Democratic Left Party (DSP), Nationalist Action Party (MHP) and Motherland Party (ANAP) were the incumbents at the time of the earthquakes.

Source:

Turkish Grand National Assembly web site (www.tbmm.gov.tr/kutuphane/hukumetler.html). 
Table 3:

Party affiliations of mayors of district centers in which at least $1 \%$ of the residences suffered heavy earthquake damage in 1999

\begin{tabular}{|l|c|c|}
\hline \multirow{2}{*}{ POLITICAL PARTIES } & \multicolumn{2}{|c|}{ Number of Mayors } \\
\cline { 2 - 3 } & $\mathbf{1 9 8 9 - 1 9 9 4}$ & $\mathbf{1 9 9 4 - 1 9 9 9}$ \\
\hline Motherland Party (ANAP) & 7 & 13 \\
\hline True Path Party (DYP) & 8 & 3 \\
\hline Republican People's Party (CHP) \& \\
Social Democratic Populist Party (SHP) & 11 & 2 \\
\hline Welfare Party (RP) & 0 & 8 \\
\hline Democratic Left Party (DSP) & 0 & 0 \\
\hline Nationalist Action Party (MHP) & 0 & 27 \\
\hline TOTAL & 26 & 1 \\
\hline
\end{tabular}

Table 3 notes:

District centers with more than 1 percent heavy damage are the following: Bolu, Düzce, Akçakoca Cumayeri, Çilimli, Gölyaka, Gümüşova, Kaynaşl1, Avcılar, Büyükçekmece, İzmit, Gölcük, Karamürsel, Körfez, Adapazarı, Akyazı, Geyve, Hendek, Karapürçek, Karasu, Kocaali, Sapanca, Yalova, Altınova, Çiftlikköy, Çınarcık and Termal. Between 1989 and 2002 the administrative division of the country has changed. The table is based on the structure prevailing in 2002. Termal was not within the boundaries of any municipality at the time of the 1989 election. Party affiliations of some mayors changed between two elections. The table reflects the distributions immediately after the elections in 1984 and 1989 . In paranthesis are the Turkish acronyms of political parties. The Republican People's Party was closed between 1983 and 1993. This party and the Social Democratic Populist Party entered the 1994 local elections seperately but they merged in 1995 .

Source:

Compiled by authors, using the data provided by the Turkish Statistical Institute (Prime Ministry, the Republic of Turkey) on the results of the 1984 and 1989 elections, and by Özmen (2000a and 2000b) on the property damage caused by the 1999 earthquakes. 
Table 4: OLS regressions

\begin{tabular}{|c|c|c|c|c|c|c|c|c|c|c|c|c|}
\hline \multirow{3}{*}{$\begin{array}{c}\begin{array}{c}\text { Independent } \\
\text { Variables }\end{array} \\
\text { CONSTANT }\end{array}$} & \multicolumn{12}{|c|}{ Equations } \\
\hline & \multicolumn{2}{|c|}{$\begin{array}{l}\text { AKP } \\
2002 \\
\end{array}$} & \multirow{2}{*}{$\begin{array}{l}\text { ANAP } \\
2002 \\
5.01^{* * *} \\
(2.76)\end{array}$} & \multirow{2}{*}{$\begin{array}{c}\text { CHP } \\
2002 \\
-14.37^{* * *} \\
(4.97)\end{array}$} & \multirow{2}{*}{$\begin{array}{l}\text { DSP } \\
2002 \\
1.36^{* * *} \\
(3.02)\end{array}$} & \multirow{2}{*}{$\begin{array}{l}\text { DYP } \\
2002 \\
\\
-6.62^{* *} \\
(1.83)\end{array}$} & \multicolumn{2}{|c|}{$\begin{array}{c}\mathrm{GP} \\
2002 \\
\end{array}$} & \multicolumn{2}{|c|}{$\begin{array}{l}\text { MHP } \\
2002 \\
\end{array}$} & \multicolumn{2}{|c|}{$\begin{array}{c}\mathrm{NV} \\
2002 \\
\end{array}$} \\
\hline & $\begin{array}{l}-6.63 \\
(0.76)\end{array}$ & $\begin{array}{l}-6.50 \\
(0.76)\end{array}$ & & & & & $\begin{array}{l}-2.32 \\
(0.54)\end{array}$ & $\begin{array}{l}-2.51 \\
(1.02)\end{array}$ & $\begin{array}{l}-2.00 \\
(0.62)\end{array}$ & $\begin{array}{l}-1.23 \\
(0.43)\end{array}$ & $\begin{array}{l}14.69^{* * *} \\
(2.59)\end{array}$ & $\begin{array}{c}17.63^{* * *} \\
(3.19)\end{array}$ \\
\hline $\begin{array}{l}\text { ANAP } \\
1999\end{array}$ & $\begin{array}{l}0.44^{* *} \\
(1.88)\end{array}$ & $\begin{array}{l}0.51^{* *} \\
(2.26)\end{array}$ & $\begin{array}{l}0.19^{* * *} \\
(3.20)\end{array}$ & $\begin{array}{c}0.07 \\
(0.82)\end{array}$ & & $\begin{array}{l}0.20^{* *} \\
(1.75)\end{array}$ & $\begin{array}{l}-0.09 \\
(0.67)\end{array}$ & $\begin{array}{l}-0.07 \\
(0.93)\end{array}$ & & & $\begin{array}{l}0.24^{* *} \\
(1.77)\end{array}$ & $\begin{array}{l}0.18 \\
(1.35)\end{array}$ \\
\hline $\begin{array}{l}\text { CHP } \\
1999\end{array}$ & & & & $\begin{array}{l}1.16^{* * *} \\
(15.07)\end{array}$ & & & & & & & & \\
\hline $\begin{array}{l}\text { DSP } \\
1999\end{array}$ & $\begin{array}{c}0.11 \\
(0.87)\end{array}$ & $\begin{array}{c}0.06 \\
(0.45)\end{array}$ & & $\begin{array}{l}0.28^{* * *} \\
(7.35)\end{array}$ & $\begin{array}{l}0.06^{* * *} \\
(8.64)\end{array}$ & $\begin{array}{l}0.19^{* * *} \\
(3.73)\end{array}$ & $\begin{array}{l}0.32^{* * *} \\
(5.46)\end{array}$ & $\begin{array}{l}0.32^{* * *} \\
(9.25)\end{array}$ & & & $\begin{array}{l}-0.09 \\
(1.24)\end{array}$ & $\begin{array}{c}-0.09 \\
(1.32)\end{array}$ \\
\hline $\begin{array}{l}\text { DYP } \\
1999\end{array}$ & $\begin{array}{l}0.43^{* * *} \\
(2.54)\end{array}$ & $\begin{array}{l}0.45^{* * *} \\
(2.75)\end{array}$ & & $\begin{array}{l}-0.01 \\
(0.21)\end{array}$ & & $\begin{array}{l}0.67^{* * *} \\
(8.16)\end{array}$ & $\begin{array}{c}0.04 \\
(0.45)\end{array}$ & $\begin{array}{l}-0.01 \\
(0.13)\end{array}$ & & & $\begin{array}{l}-0.15^{*} \\
(1.34)\end{array}$ & $\begin{array}{l}-0.18^{* *} \\
(1.67)\end{array}$ \\
\hline $\begin{array}{c}\text { FP } \\
1999\end{array}$ & $\begin{array}{l}1.35^{* * *} \\
(8.27)\end{array}$ & $\begin{array}{l}1.29^{* *} \\
(7.62)\end{array}$ & & & & & & & & & & \\
\hline $\begin{array}{l}\text { MHP } \\
1999\end{array}$ & $\begin{array}{l}0.54^{* * *} \\
(4.43)\end{array}$ & $\begin{array}{l}0.52^{* * *} \\
(4.39)\end{array}$ & & $\begin{array}{c}0.02 \\
(0.49)\end{array}$ & & $\begin{array}{r}0.06 \\
(1.06)\end{array}$ & $\begin{array}{c}0.03 \\
(0.42)\end{array}$ & $\begin{array}{c}0.04 \\
(0.90)\end{array}$ & $\begin{array}{l}0.28^{* * *} \\
(5.34)\end{array}$ & $\begin{array}{l}0.28^{* * *} \\
(6.19)\end{array}$ & $\begin{array}{c}0.06 \\
(0.69)\end{array}$ & $\begin{array}{c}0.04 \\
(0.52)\end{array}$ \\
\hline $\begin{array}{l}\mathrm{NV} \\
1999\end{array}$ & & & & & & & & & & & $\begin{array}{l}1.19^{* * *} \\
(7.94)\end{array}$ & $\begin{array}{l}1.12^{* * *} \\
(7.72)\end{array}$ \\
\hline $\begin{array}{l}\text { MEAN YEARS OF } \\
\text { SCHOOLING (S) }\end{array}$ & $\begin{array}{l}-1.40 \\
(0.94)\end{array}$ & $\begin{array}{l}-1.51 \\
(1.05)\end{array}$ & $\begin{array}{l}-0.02 \\
(0.04)\end{array}$ & $\begin{array}{l}2.97^{* * *} \\
(5.21)\end{array}$ & $\begin{array}{l}-0.10 \\
(0.97)\end{array}$ & $\begin{array}{c}1.21^{*} \\
(1.63)\end{array}$ & $\begin{array}{l}-0.05 \\
(0.06)\end{array}$ & $\begin{array}{c}0.18 \\
(0.37)\end{array}$ & $\begin{array}{c}0.95^{*} \\
(1.33)\end{array}$ & $\begin{array}{c}0.82^{*} \\
(1.31)\end{array}$ & $\begin{array}{l}-1.53^{* *} \\
(1.70)\end{array}$ & $\begin{array}{c}-1.60^{* *} \\
(1.87)\end{array}$ \\
\hline $\begin{array}{l}\text { URBANIZATION } \\
\text { RATE (U) }\end{array}$ & $\begin{array}{c}8.27^{*} \\
(1.39)\end{array}$ & $\begin{array}{l}11.46^{* *} \\
(1.93)\end{array}$ & $\begin{array}{l}-7.03^{* * *} \\
(4.23)\end{array}$ & $\begin{array}{l}-5.94^{* * *} \\
(2.59)\end{array}$ & $\begin{array}{l}-1.17^{* * *} \\
(2.99)\end{array}$ & $\begin{array}{l}-8.12^{* * *} \\
(2.77)\end{array}$ & $\begin{array}{l}2.93 \\
(0.85)\end{array}$ & $\begin{array}{c}0.81 \\
(0.40)\end{array}$ & $\begin{array}{l}-2.75 \\
(1.06)\end{array}$ & $\begin{array}{l}-3.07^{*} \\
(1.34)\end{array}$ & $\begin{array}{l}-0.43 \\
(0.12)\end{array}$ & $\begin{array}{l}-1.22 \\
(0.36)\end{array}$ \\
\hline $\begin{array}{c}\text { PROP. OF } \\
\text { WOMEN IN NON- } \\
\text { AGR. EMPL.(W) }\end{array}$ & $\begin{array}{l}-5.06 \\
(0.23)\end{array}$ & $\begin{array}{l}-9.14 \\
(0.42)\end{array}$ & $\begin{array}{l}9.24^{* *} \\
(1.67)\end{array}$ & $\begin{array}{l}13.37^{*} \\
(1.59)\end{array}$ & $\begin{array}{l}-0.74 \\
(0.47)\end{array}$ & $\begin{array}{l}-1.66 \\
(0.15)\end{array}$ & $\begin{array}{c}0.99 \\
(0.08)\end{array}$ & $\begin{array}{c}4.67 \\
(0.62)\end{array}$ & $\begin{array}{r}7.26 \\
(0.79)\end{array}$ & $\begin{array}{c}7.84 \\
(0.98)\end{array}$ & $\begin{array}{l}-1.65 \\
(0.12)\end{array}$ & $\begin{array}{l}-0.90 \\
(0.07)\end{array}$ \\
\hline $\begin{array}{c}\text { QUAKE } \\
\text { DAMAGE PER } \\
\text { 100 PEOPLE (Q) }\end{array}$ & $\begin{array}{c}0.38 \\
(0.82)\end{array}$ & $\begin{array}{c}1.79^{* *} \\
(2.25)\end{array}$ & $\begin{array}{l}-0.21^{* *} \\
(1.69)\end{array}$ & $\begin{array}{l}-0.37^{* *} \\
(2.21)\end{array}$ & $\begin{array}{l}-0.04^{*} \\
(1.46)\end{array}$ & $\begin{array}{l}-0.58^{* * *} \\
(2.71)\end{array}$ & $\begin{array}{c}0.60^{* * *} \\
(2.39)\end{array}$ & $\begin{array}{c}0.07 \\
(0.45)\end{array}$ & $\begin{array}{c}0.05 \\
(0.26)\end{array}$ & $\begin{array}{c}-0.77^{* * *} \\
(2.90)\end{array}$ & $\begin{array}{l}-0.45^{* *} \\
(1.71)\end{array}$ & $\begin{array}{l}-1.13^{* *} \\
(3.08)\end{array}$ \\
\hline SAKARYA & & $\begin{array}{r}-10.07^{*} \\
(2.00)\end{array}$ & & & & & & $\begin{array}{l}16.06^{* *} \\
(10.27)\end{array}$ & & & & \\
\hline YALOVA & & $\begin{array}{r}-15.45^{*} \\
(1.95)\end{array}$ & & & & & & & & $\begin{array}{c}11.93^{* * *} \\
(4.14)\end{array}$ & & $\begin{array}{c}10.25^{* * *} \\
(2.53)\end{array}$ \\
\hline R-Square & 0.81 & 0.83 & 0.49 & 0.93 & 0.70 & 0.77 & 0.60 & 0.87 & 0.40 & 0.54 & 0.79 & 0.82 \\
\hline Adj. R-square & 0.78 & 0.79 & 0.44 & 0.91 & 0.67 & 0.74 & 0.54 & 0.85 & 0.34 & 0.49 & 0.76 & 0.78 \\
\hline $\begin{array}{c}\mathrm{F} \\
(\mathrm{prob}>\mathrm{F})\end{array}$ & $\begin{array}{l}24.57 \\
(0.00)\end{array}$ & $\begin{array}{l}21.95 \\
(0.00)\end{array}$ & $\begin{array}{l}10.46 \\
(0.00)\end{array}$ & $\begin{array}{l}71.61 \\
(0.00)\end{array}$ & $\begin{array}{l}25.71 \\
(0.00)\end{array}$ & $\begin{array}{l}21.96 \\
(0.00)\end{array}$ & $\begin{array}{c}9.80 \\
(0.00)\end{array}$ & $\begin{array}{l}37.94 \\
(0.00)\end{array}$ & $\begin{array}{c}7.24 \\
(0.00)\end{array}$ & $\begin{array}{l}10.65 \\
(0.00)\end{array}$ & $\begin{array}{l}21.75 \\
(0.00)\end{array}$ & $\begin{array}{l}22.29 \\
(0.00)\end{array}$ \\
\hline $\begin{array}{l}\text { White Chi-square } \\
\text { (prob }>\text { Chi- } \\
\text { square) }\end{array}$ & $\begin{array}{l}48.22 \\
(0.70)\end{array}$ & $\begin{array}{l}54.00 \\
(0.62)\end{array}$ & $\begin{array}{l}19.42 \\
(0.49)\end{array}$ & $\begin{array}{l}54.95 \\
(0.40)\end{array}$ & $\begin{array}{l}26.35 \\
(0.15)\end{array}$ & $\begin{array}{l}42.27 \\
(0.55)\end{array}$ & $\begin{array}{l}20.35 \\
(1.00)\end{array}$ & $\begin{array}{l}46.33 \\
(0.42)\end{array}$ & $\begin{array}{l}11.10 \\
(0.94)\end{array}$ & $\begin{array}{l}13.67 \\
(0.88)\end{array}$ & $\begin{array}{l}33.76 \\
(0.98)\end{array}$ & $\begin{array}{l}44.17 \\
(0.87)\end{array}$ \\
\hline
\end{tabular}


Table 4 notes:

For the definitions of variables, see Section 3. The sample includes 61 provinces, excluding the following 20 provinces: Ağrı, Bingöl, Bitlis, Diyarbakır, Hakkari, Kars, Mardin, Muş, Rize, Siirt, Tunceli, Şanlıurfa, Van, Bayburt, Batman, Şırnak, Bartın, Ardahan, Iğdır, and Osmaniye. Only 10 percent of the registered voters resided in the latter provinces in 2002. In 1999 the administrative division of the country was slightly different. The structure prevailing in 2002 is used. The equations are estimated using Ordinary Least Squares method, utilizing the REG procedure of SAS (2008) statistical package. The numbers in parantheses below the parameter estimates are the t-values in absolute value. A superscript with a single asterisk refers to significance at 10 percent level, a superscript with a double asterisk, to significance at 5 percent level, and a superscript with triple asterisk to significance at 1 percent level (in one-tail tests).

\section{Source:}

Regressions are computed by the authors. The vote shares of political parties are computed using the data provided by the Turkish Statistical Institute (Prime Ministry, the Republic of Turkey) on the results of the 1999 and 2002 elections. $\mathrm{S}, \mathrm{U}$, and $\mathrm{W}$ variables are computed utilizing the 2000 Census data provided by the Turkish Statistical Institute. In computing mean years of schooling $(\mathrm{S})$ for each province, 15, 11, 8, and 5 years of schooling are attributed respectively, to university, high school, middle school, and primary school graduates in the province. Two years worth of schooling is assumed for those who are literate but not a graduate of any school. The Q variable is constructed by dividing the second column of Table 1 by 100 . 
Table 5: Robust regressions

\begin{tabular}{|c|c|c|c|c|c|c|c|c|}
\hline \multirow{2}{*}{$\begin{array}{l}\text { Independent } \\
\text { Variables }\end{array}$} & \multicolumn{8}{|c|}{ Equations } \\
\hline & $\begin{array}{l}\text { AKP } \\
2002 \\
\end{array}$ & $\begin{array}{l}\text { ANAP } \\
2002 \\
\end{array}$ & $\begin{array}{l}\text { CHP } \\
2002 \\
\end{array}$ & $\begin{array}{l}\text { DSP } \\
2002 \\
\end{array}$ & $\begin{array}{l}\text { DYP } \\
2002 \\
\end{array}$ & $\begin{array}{c}\text { GP } \\
2002 \\
\end{array}$ & $\begin{array}{l}\text { MHP } \\
2002 \\
\end{array}$ & $\begin{array}{c}\mathrm{NV} \\
2002 \\
\end{array}$ \\
\hline CONSTANT & $\begin{array}{l}-3.65 \\
(0.25)\end{array}$ & $\begin{array}{l}-3.32^{* * *} \\
(6.23)\end{array}$ & $\begin{array}{l}-5.52^{*} \\
(3.36)\end{array}$ & $\begin{array}{c}1.14^{* * * *} \\
(12.89)\end{array}$ & $\begin{array}{l}-5.05 \\
(2.23)\end{array}$ & $\begin{array}{l}-2.60 \\
(1.59)\end{array}$ & $\begin{array}{c}0.21 \\
(0.01)\end{array}$ & $\begin{array}{l}9.79^{* * *} \\
(4.87)\end{array}$ \\
\hline $\begin{array}{l}\text { ANAP } \\
1999\end{array}$ & $\begin{array}{c}0.70^{* * *} \\
(12.29)\end{array}$ & $\begin{array}{c}0.38^{* * *} \\
(58.15)\end{array}$ & $\begin{array}{l}-0.15 \\
(2.69)\end{array}$ & & $\begin{array}{l}0.17^{*} \\
(2.73)\end{array}$ & $\begin{array}{l}-0.04 \\
(0.39)\end{array}$ & & $\begin{array}{l}0.18^{*} \\
(3.41)\end{array}$ \\
\hline $\begin{array}{l}\text { CHP } \\
1999\end{array}$ & & & $\begin{array}{r}1.20^{* * * *} \\
(291.53)\end{array}$ & & & & & \\
\hline $\begin{array}{l}\text { DSP } \\
1999\end{array}$ & $\begin{array}{c}0.03 \\
(0.04)\end{array}$ & & $\begin{array}{c}0.28^{* * *} \\
(53.96)\end{array}$ & $\begin{array}{c}0.05^{* * *} \\
(82.32)\end{array}$ & $\begin{array}{c}0.19^{* * *} \\
(15.70)\end{array}$ & $\begin{array}{c}0.27^{* * *} \\
(73.53)\end{array}$ & & $\begin{array}{c}0.01 \\
(0.01)\end{array}$ \\
\hline $\begin{array}{l}\text { DYP } \\
1999\end{array}$ & $\begin{array}{c}0.59^{* * *} \\
(16.23)\end{array}$ & & $\begin{array}{l}-0.06 \\
(0.92)\end{array}$ & & $\begin{array}{l}0.63^{* * *} \\
(67.70)\end{array}$ & $\begin{array}{c}0.03 \\
(0.42)\end{array}$ & & $\begin{array}{l}-0.17^{*} \\
(4.27)\end{array}$ \\
\hline $\begin{array}{c}\text { FP } \\
1999\end{array}$ & $\begin{array}{c}1.40^{* * *} \\
(65.22)\end{array}$ & & & & & & & \\
\hline $\begin{array}{l}\text { MHP } \\
1999\end{array}$ & $\begin{array}{l}0.44^{* * *} \\
(17.39)\end{array}$ & & $\begin{array}{l}-0.06 \\
(2.32)\end{array}$ & & $\begin{array}{c}0.07 \\
(1.58)\end{array}$ & $\begin{array}{c}0.03 \\
(0.99)\end{array}$ & $\begin{array}{l}0.24^{* * *} \\
(33.74)\end{array}$ & $\begin{array}{r}0.09 \\
(1.78)\end{array}$ \\
\hline $\begin{array}{l}\text { NV } \\
1999\end{array}$ & & & & & & & & $\begin{array}{r}1.34^{* * *} \\
(134.89)\end{array}$ \\
\hline $\begin{array}{l}\text { MEAN YEARS OF } \\
\text { SCHOOLING (S) }\end{array}$ & $\begin{array}{l}-2.78^{* *} \\
(4.86)\end{array}$ & $\begin{array}{c}0.05 \\
(0.02)\end{array}$ & $\begin{array}{c}2.31^{* * *} \\
(21.85)\end{array}$ & $\begin{array}{l}-0.07 \\
(0.94)\end{array}$ & $\begin{array}{c}1.01 \\
(2.12)\end{array}$ & $\begin{array}{c}0.23 \\
(0.29)\end{array}$ & $\begin{array}{c}0.83 \\
(2.40)\end{array}$ & $\begin{array}{l}-0.89 \\
(2.00)\end{array}$ \\
\hline $\begin{array}{l}\text { URBANIZATION } \\
\text { RATE (U) }\end{array}$ & $\begin{array}{l}13.53^{* * *} \\
(6.74)\end{array}$ & $\begin{array}{l}-4.59^{* * *} \\
(14.63)\end{array}$ & $\begin{array}{l}-11.73^{* * *} \\
(28.65)\end{array}$ & $\begin{array}{l}-0.92^{* * *} \\
(12.40)\end{array}$ & $\begin{array}{l}-8.99^{* * *} \\
(10.81)\end{array}$ & $\begin{array}{c}0.10 \\
(0.00)\end{array}$ & $\begin{array}{l}-3.65^{*} \\
(3.50)\end{array}$ & $\begin{array}{c}0.16 \\
(0.00)\end{array}$ \\
\hline $\begin{array}{c}\text { PROP. OF } \\
\text { WOMEN IN NON- } \\
\text { AGR. EMPL.(W) }\end{array}$ & $\begin{array}{l}-11.28 \\
(0.36)\end{array}$ & $\begin{array}{l}-2.23 \\
(0.25)\end{array}$ & $\begin{array}{l}29.99^{* * *} \\
(13.46)\end{array}$ & $\begin{array}{l}-0.56 \\
(0.24)\end{array}$ & $\begin{array}{c}1.98 \\
(0.04)\end{array}$ & $\begin{array}{c}6.46 \\
(0.91)\end{array}$ & $\begin{array}{c}4.73 \\
(0.46)\end{array}$ & $\begin{array}{r}-15.38^{*} \\
(2.81)\end{array}$ \\
\hline $\begin{array}{c}\text { QUAKE } \\
\text { DAMAGE PER } 100 \\
\text { PEOPLE (Q) }\end{array}$ & $\begin{array}{l}1.47^{* *} \\
(4.84)\end{array}$ & $\begin{array}{l}-0.28^{* * *} \\
(10.78)\end{array}$ & $\begin{array}{l}-0.77^{* * *} \\
(15.29)\end{array}$ & $\begin{array}{l}-0.03^{*} \\
(2.93)\end{array}$ & $\begin{array}{l}-0.54^{* * *} \\
(7.50)\end{array}$ & $\begin{array}{c}0.07 \\
(0.31)\end{array}$ & $\begin{array}{l}-0.76^{* * *} \\
(11.10)\end{array}$ & $\begin{array}{l}-0.46 \\
(2.52)\end{array}$ \\
\hline SAKARYA & $\begin{array}{c}-11.50^{* * *} \\
(7.52)\end{array}$ & & & & & $\begin{array}{l}16.06^{* * *} \\
(150.57)\end{array}$ & & \\
\hline YALOVA & $\begin{array}{c}-14.37^{* *} \\
(4.78)\end{array}$ & & & & & & $\begin{array}{l}11.64^{* * *} \\
(22.42)\end{array}$ & $\begin{array}{c}4.01 \\
(1.75)\end{array}$ \\
\hline
\end{tabular}


Table 5 notes:

For the definitions of variables, see Section 3. The sample includes 61 provinces, excluding the following 20 provinces: Ağrı, Bingöl, Bitlis, Diyarbakır, Hakkari, Kars, Mardin, Muş, Rize, Siirt, Tunceli, Şanlıurfa, Van, Bayburt, Batman, Şırnak, Bartın, Ardahan, Iğdır, and Osmaniye. Only 10 percent of the registered voters resided in the latter provinces in 2002. In 1999 the administrative division of the country was slightly different. The structure prevailing in 2002 is used. The equations are estimated using the ROBUSTREG procedure of SAS (2008) statistical package. In particular, the least trimmed squares (LTS) method developed by Rousseeuw (1984), Rousseeuw and Van Driessen (2000) and Zaman et al. (2001) is utilized. The following observations are picked by the algorithm as outliers: Adıyaman Gümüşhane and Kilis in the AKP equation, Antalya, Isparta, Kütahya, Karaman and Kırıkkale in the ANAP equation, Adiyaman, Denizli, Hatay, Isparta, Malatya, Zonguldak, Kırıkkale and Yalova in the CHP equation, Adiyaman, Edirne, Kastamonu, Kırklareli and Kilis in the DSP equation, Bilecik in the DYP equation, Artvin, Edirne and İzmir in the GP equation, Kırşehir and Mersin in the MHP equation, and Adıyaman, Çankırı, Erzurum, Kocaeli and Niğde, in the NV equation. The parameter values reported in the table are the final weighted least squares (FWLS) estimates. The numbers in parantheses below the parameter estimates are the chi-square values. A superscript with a single asterisk refers to significance at 10 percent level, a superscript with a double asterisk, to significance at 5 percent level, and a superscript with triple asterisk to significance at 1 percent level (in one-tail tests).

Source:

Regressions are computed by the authors. The vote shares of political parties are computed using the data provided by the Turkish Statistical Institute (Prime Ministry, the Republic of Turkey) on the results of the 1999 and 2002 elections. $\mathrm{S}$, U, and $\mathrm{W}$ variables are computed utilizing the 2000 Census data provided by the Turkish Statistical Institute. In computing mean years of schooling $(\mathrm{S})$ for each province, 15, 11, 8, and 5 years of schooling are attributed respectively, to university, high school, middle school, and primary school graduates in the province. Two years worth of schooling is assumed for those who are literate but not a graduate of any school. The Q variable is constructed by dividing the second column of Table 1 by 100 . 
FIGURE 1:

PROVINCES WHICH SUFFERED HEAVY EARTHQUAKE DAMAGE IN 1999



Source: Table 1, Table 4 and Table 5 notes. 